\title{
Formulating Business Model Wedding Website Platform during Covid-19 Pandemic
}

\author{
Jatmika Prajayastanda ${ }^{1}$, Handy Nur Cahya ${ }^{2}$ \\ \{jatmikaprajayastanda@lecturer.undip.ac.id,handy.nur@dsn.dinus.ac.id\}
}

Business and Finance Department, Vocational School Diponegoro University, Semarang ${ }^{1}$ Management Department, Economic, and Business Dian Nuswantoro University, Semarang 2

\begin{abstract}
Marriage has always been being one of the important events that occur in every human life cycle. The number of marriages is running high from a year to year basis. In Indonesia there are 1,8 million marriages occur each year in 2015-2017. It is nearly impossible during the Covid-19 pandemic invasion to carry a regular marriage event like ever before. The Government restricts crowd-gathering activities, such as the wedding party, to tackle the Covid-19 outbreaks. It causes people who want to get married quite worried, delay, or even cancel the wedding party. Technology plays a significant role in developing innovation. Online wedding receptions are the solution. Wemary is a startup engaged in a marriage that offers innovative integrated wedding services such as online reception. These research aims are to develop and modify Wemary's business model through the business model canvas approximation. A qualitative method was used in this study. Data are collected from an interview with CV Putra Nugraha Wedding, the survey with twenty-five potential customers, and literacy assessments. This study indicates the Wemary service was exciting and worth a try, but for some elderly, Wemary service seems uncommon. This research uses primary data obtained from the analysis of two different kinds of questionnaires and interviews. This study develops the business.
\end{abstract}

Keywords: Business Model, Wedding, Website Platform, Covid-19 Pandemic

\section{Introduction}

Technology plays a significant role in developing innovation moves with the times. The government's appeal regarding social distancing has caused various events, one of which is the marriage to be postponed or even canceled. This aim to decrease widespread of the coronavirus. In the current era of the COVID-19 pandemic, online wedding receptions are solutions.

Wemary is a startup that develops innovations to help wedding services. As a sacred and special moment, the bride and groom and the bride and groom's parents want a perfect marriage hoping that those around them can also feel their happiness. When planning and preparing for a wedding, some couples do not have enough time to prepare for their wedding party. The services of a wedding organizer are considered to save time and can even be cheaper. The need for the use of wedding organizers among Indonesians who live in urban areas is increasing from time to time.

Each wedding event series presents many business opportunities ranging from wedding organizers, invitation printing, building rentals, catering, rental of dresses, make-up, souvenirs, 
rental of tents, photographers, and videographers, even to wedding delivery. However, no one has yet offered an exclusive wedding website that allows the bride and groom to interact more through a wedding website service developed by Wemary.

The company develops innovative services, an integrated website that connects brides and invited guests exclusively. Sharing the wedding news is very easy; with the touch of a finger, the invitation can be immediately accepted by invited guests wherever they are. The invitation is in the form of an exclusive online invitation that can be shared via social media, such as Whatsapp, Line, Facebook, Twitter, and even Google+. This service can minimize paper usage so that it is environmentally friendly to provide a wedding.

The wedding website also provides more opportunities for brides to share their love stories with guests through the Love Story feature. With this feature, the bride and groom can tell more through writing, pictures, or videos about their love stories that they cannot write through paper invitation

Guests who have no chance to come to the marriage party due to time and distance limitations do not have to worry. Wemary offers a solution; on the Wemary wedding website, there is feature called Find a Gift. There are several unique item available as a wedding gift customer can pick, which of course the item is specially prepared based on the preferences of the bride and groom best match product. Wemary also help pack and deliver the wedding ceremony. Currently, wedding live stream service, are being developt.

The term startup has been busy talking currently to describe new companies, especially companies engaged in technology and the internet. The word startup is an English loan word that shows a new business. According to Nadiem Makarim, a Co-Founder and of Gojek, "A startup is a company that works to solve problems with a solution, but its success is not guaranteed" [12]. A startup is a company designed to create new goods or services in conditions of uncertainty. extreme [9]. Steve Blank, a professor from Stanford, initiated another definition; a startup is an organization formed to find a scalable and repeatable business model. From these studies, several essential points about the term startup can be formulated. Namely, startups are companies newly established, have product innovation, and even business. Their business model has not been assessed and is engaged in technology.

Today's business environment is extremely competitive, rapidly changing, and it is increasingly challenging for companies to make business decisions [1]. Consumers get information very quickly. Companies are plagued with developments in information technology, shorter product life cycles, global markets, and competitive competition. The current business environment provides new companies or startups opportunities to enter by offering something new to consumers.

Startup companies typically offer innovation in products and businesses. Talking about the innovation business model carries out a unique role in innovation. It is essential to pay attention to in a business environment that is changing rapidly and increasingly complex [6] [10]. Unlike the innovations generated from the research and development department, the model's innovation departs from across functions that form and capture customers' new value. The most important business model innovation component lies in a deeper understanding of what consumers want and what consumer needs are unfulfilled.

The ideas around the concept of a business model have begun to be discussed by researchers and businesses [14]. In five years, the results show that companies which carry out business models earn higher profits than conventional companies. As additional information, 14 of the 25 most innovative companies worldwide are innovating business models [2]. Other studies indicate the business model is the main innovation factor in innovation related to business success and sustainability [5]. 
Innovation has always comprised an essential factor for driving growth and competitiveness in running a business. Almost every industry today, insufficient enough to rely solely on product excellence or process innovation. Nowadays, it's very easy for people to replicate a business, thats why the business model is necessary.

The term business model is familiar to both academics and business actors. The business model is a logic for how a company supports itself financially [4]. Business models can help visualize how the company operates, identify, and describe what consumers want and find out how to earn money and even satisfy consumers.

Another opinion regarding business models is that business models explain the rationale for how organizations form, run, deliver, and capture value using nine building block components [8]. This business model concept will transform to become a language that ease business actors to describe and manipulate business and create other new strategies. It can be concluded that academics and business actors explain a business model's meaning in three groups:

1. A business model as a method or way of running a business.

2. A business model seen from the aspects of business components.

3. A business model as a business strategy.

The purpose of a simple business model is the formulation of a strategy to protect the company's competitive advantage [13]. The value offered to consumers will be well received as a loyalty if formulated through the right business model strategy. Meanwhile, the business model itself will be able act as a tool or approach to creating value for consumer which come internally and externally [14].

The functionality of describing business models can provide several benefits:

1. An explicit business model will help companies get information about how, where, and when they function correctly.

2. Designing a profitable business model can weaken other competitors.

3. Having an explicit business model is capable of turning competitors into allies [11].

In most cases, the components of a business model can describe the entire business model in value creation. Based on the various definitions of business models by several researchers and business actors, various opinions have already made about the business model's components. The concept of a business model with nine components is commonly known as the Nine Building Block Business Model Concept or the Canvas Business Model. This concept is one of the most attractive business model methods and can describe a whole company's business processes [8].

This canvas business model is visualized with nine components, comprise the value proposition, customer segments, channels, key activities, customer relationships, key partnerships, key resources, revenue streams, and cost structure. These nine components are arranged on a canvas to make it easier to read and see the relationship between variables within the company, as depicted in Figure 1. 


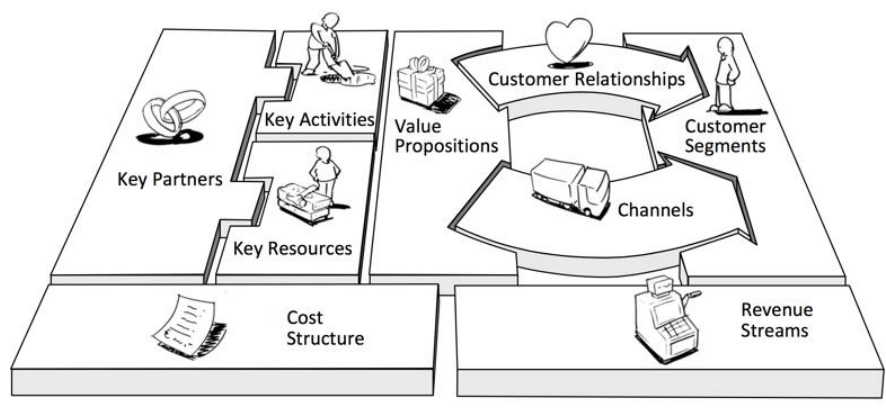

Fig 1. Canvas Model Business

A simple explanation of this business model is the value proposition as the axis of the business model. There are three parts to the business model canvas. The first parts on the right side of the value proposition have three components, which are things related to consumers, the second parts on the left side of the value proposition have three components, which are activities to produce goods or services, and the third parts are at the bottom of the value proposition is a description of the company's income and expenses. The business model's description using the canvas business model method is a simple analysis and includes all the variables that exist within the company. Developing a business model for innovation and development can use several techniques. There are six techniques in designing business models: customer insights, idea formation, visual thinking, prototyping, storytelling, and scenarios [8].

One of the keys to a company's success in offering products or services is understanding the needs of potential customers, commonly known as customer insight. The main principle in compiling a business model is to use customer insight to determine the customer's perspective through an empathy map. Empathy maps can be used by businesses and researchers to determine consumer characteristics so that consumer profiles can be known. Empathy maps as a tool that can help in understanding the customer's perspective based on what they see, think and feel, say and do, worry, and what consumers want to get to develop a new proportion of value. Figure 2 presents a visualization of the empathy map.

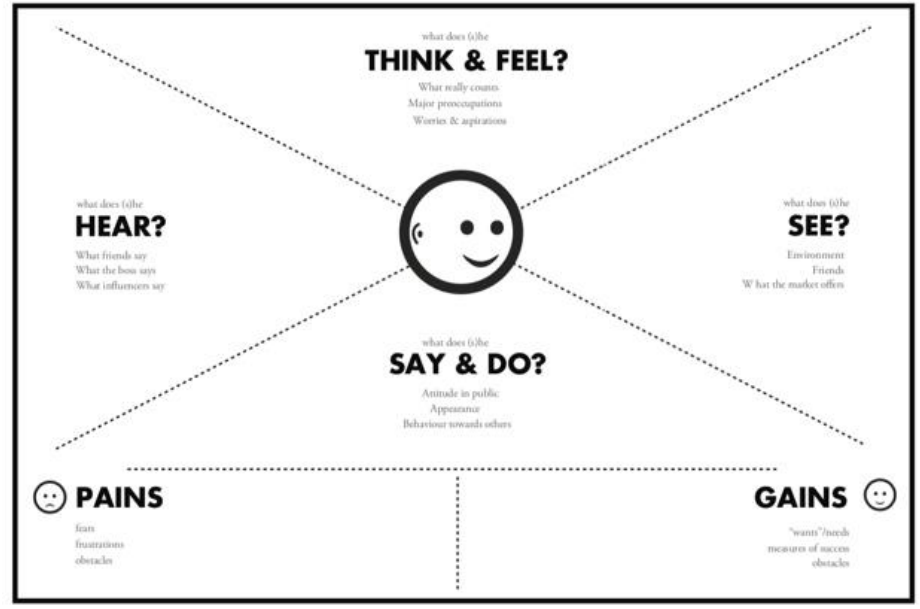

Fig 2. Empathy Map 
The figure above is an overview of the steps needed to get customer insight from customers [8]. The purpose of making an empathy map is brainstorming to find the market segment you want to serve, finding customer characteristics, and building customer profiles.

\section{Methodology}

Wemary's research business model uses qualitative research methods. Qualitative research methods are used to obtain data sources in the form of opinions from potential customers, to find out the images and expectations of consumers for integrated wedding website platform services that offer the convenience of sharing happiness between the bride and groom and guests.

The unit of analysis in this study is Wemary's potential customers. This research is intended to describe costumers" characteristics and behaviour who have an integrated wedding website service developed by Wemary. Ideas and input from potential Wemary customers can help in preparing Wemary's business model. This study's sampling technique is a nonprobability purposive sampling technique that includes people selected based on specific criteria.

The data source of this research uses primary and secondary data. Primary data obtained through interviews (in-depth interviews) and distributing questionnaires. Secondary data is obtained through a literature review from the internet, articles, journals, and books. The sources and methods of collecting research data are summarized in Table 1.

Table 1. Research Sources and Methods

\begin{tabular}{cccc}
\hline Data & Method & Research Process & Information Obtained \\
\hline \multirow{2}{*}{ Primary } & $\begin{array}{c}\text { In-depth } \\
\text { Interview }\end{array}$ & $\begin{array}{c}\text { Interview with Founder CV Putra } \\
\text { Nugraha Wedding }\end{array}$ & $\begin{array}{c}\text { General description of the } \\
\text { marriage and collaboration } \\
\text { business run by CV Putra } \\
\text { Nugraha Wedding }\end{array}$ \\
\cline { 2 - 4 } & Questionnaire & $\begin{array}{c}\text { Distribution of questionnaires to 25 } \\
\text { potential Wemary customers aged } \\
17 \text { to 40 years }\end{array}$ & $\begin{array}{c}\text { Determination of market } \\
\text { segments to be served, along } \\
\text { with a description of consumer } \\
\text { characteristics and profiles }\end{array}$ \\
\hline Secondary & $\begin{array}{c}\text { Literature } \\
\text { Review }\end{array}$ & $\begin{array}{c}\text { Conducting literature reviews from } \\
\text { the internet, articles, journals, and } \\
\text { books related to marriage business } \\
\text { information }\end{array}$ & $\begin{array}{c}\text { Understanding of theory, } \\
\text { business concepts, cooperation, } \\
\text { and analysis of competition in } \\
\text { the marriage industry }\end{array}$ \\
\hline
\end{tabular}




\section{Finding and Discussion}

This chapter describes the research results, which are divided into three parts. The first part provides an overview of the wedding planner business model, which is used to develop Wemary's business model. The second part analyzes customer perspectives and insights through empathy maps. The third part is Wemary's business model. The design of Wemary's business model is depicted with a business canvas model through the Wedding Organizer "CV Putra Nugraha Wedding" business model approach and the results of distributing questionnaires that are poured into an empathy map.

\subsection{Wedding Business Model of CV Putra Nugraha}

CV Putra Nugraha Wedding was established in 2011. Its history begins with helping one of the wedding planners in Yogyakarta to prepare for a wedding. CV Putra Nugraha Wedding's business will be described in the following section. Table 2 below is the result of the researcher's interview with CV Putra Nugraha of customer segment, value proposition, channel, and customer relationship.

Table 2. Result of interview with CV Putra Nugraha of Customer Segment, Value Proposition, Channel, and Customer Relationship

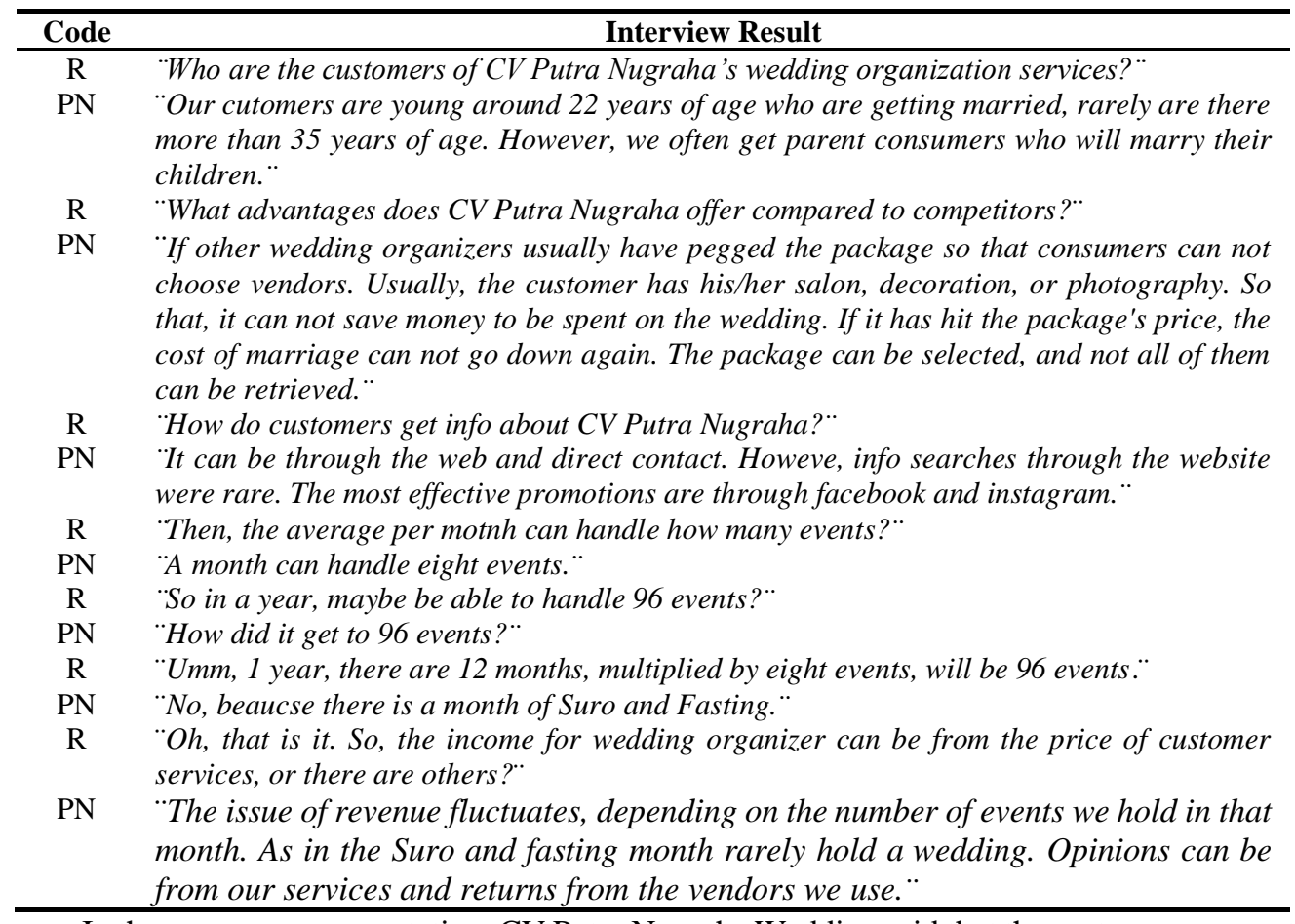

In the consumer segmentation, CV Putra Nugraha Wedding said that the customer segment is prospective young couples around the age of 21 years and over who do not have time to arrange marriage. Consumers who come are young people and parents who will hold a wedding for their child. CV Putra Nugraha Wedding always offers a creative wedding concept but according to the consumer's budget. The packages offered can be modified according to consumer desires. This is an advantage offered over competitors. 
The means for promoting CV Putra Nugraha Wedding services are currently using websites and social media. The social media used are Facebook and Instagram because potential consumers for marriage are young people who are familiar with social media in their daily activities. Usually, prospective customers contact CV Putra Nugraha Wedding then make an appointment to meet and discuss the concept of marriage that consumers want. To convince consumers, personal assistance is provided. This method is considered useful in approaching the concept offered in accordance with what consumers want. The role and responsibility of personal assistance are not only when creating the event's concept but also when accompanying the bride and groom and their family until the end of the events. This is done to ensure customer satisfaction. The income earned by CV Putra Nugraha Wedding comes from direct revenue from sales of services and commissions from cooperating vendors. Every month, the average person can hold eight weddings to maintain a stable income because, in certain months, such as the month of Suro and Fasting, the demand for wedding services will below.

In other words, the key to holding a wedding is key resources, key activities, key partnerships, and cost structures. Table 3 below is the result of the researcher's interview with CV Putra Nugraha of key resources, key activities, key partnetships, and cost structures.

Table 3. Result of interview with CV Putra Nugraha of Key Resources, Key Activities, Key Partnerships, and Cost Structures

\begin{tabular}{|c|c|}
\hline Code & Interview Result \\
\hline Question & "How many empleyees at CV Putra Nugraha?". \\
\hline Answer & $\begin{array}{l}\text { "There are no permanent employees, but there is freelance, depending on the number } \\
\text { of guest. Usually, if the guest is about } 500 \text { invitations, we send } 4-5 \text { people. The } \\
\text { calculation is that one person can handle up to } 200 \text { guests." }\end{array}$ \\
\hline Question & $\begin{array}{l}\text { "Oh, that is it. Then, what activities does CV Putra Nugraha do to maintain the } \\
\text { wedding organizer business?.* }\end{array}$ \\
\hline Answer & $\begin{array}{l}\text { "The priority of the activity is promotion. The promotion is done by participating in } \\
\text { wedding expos and online promotions through social media." }\end{array}$ \\
\hline Question & "Does the weding organizer have cooperation with vendors?". \\
\hline Answer & $\begin{array}{l}\text { "We have cooperation with catering, make-up, photographers, except decoration. Our } \\
\text { decoration have their own." }\end{array}$ \\
\hline Question & "Then, how much capital is needed when initially creating a wedding business?" \\
\hline Answer & $\begin{array}{l}\text { "Our capital is not very large. For every wedding event, we apply a down payment } \\
\text { deal in advance, so i tis safe." }\end{array}$ \\
\hline
\end{tabular}

Resources are one of the supporting factors for the success of a business. Based on the interview results, CV Putra Nugraha Wedding divides the portion of human resources responsible for a wedding based on the number of guests invited. The count of each person can accommodate 200 people in order to maintain the quality of the event.

The main activity of CV Putra Nugraha Wedding is to promote so that people use their services. Promotional activities carried out are by participating in wedding fairs and online promotions through social media. Social media is considered the most effective at this time to carry out promotions, frequent engagement from consumers through social media. The concept of events and photos from social media often inspire consumers.

One of the keys to business success is establishing several partnerships with several partners. In running the business, CV Putra Nugraha Wedding utilizes cooperation with several partners, including catering, photographers, location providers, make-up service providers, and invitation printing. Collaboration with several partners provides financial and non-financial benefits. This financial benefit is obtained by getting a commission for the use of services. In 
contrast, the non-financial benefit is the efficiency of the portion of work following each job specialization.

Based on the results of an interview with the owner of CV Putra Nugraha Wedding, the cost required to set up this business does not require too much investment value. Some wedding operational costs can be covered with an advance agreement from the bride and groom, and the costs incurred are by the number of guests to be invited. Often operational costs swell in line with increasing consumer demand.

Based on the interviews and analysis results, it can be seen that an overview of CV Putra Nugraha Wedding's business model. The CV Putra Nugraha Marriage Business Model Canvas can be seen in Figure 3.

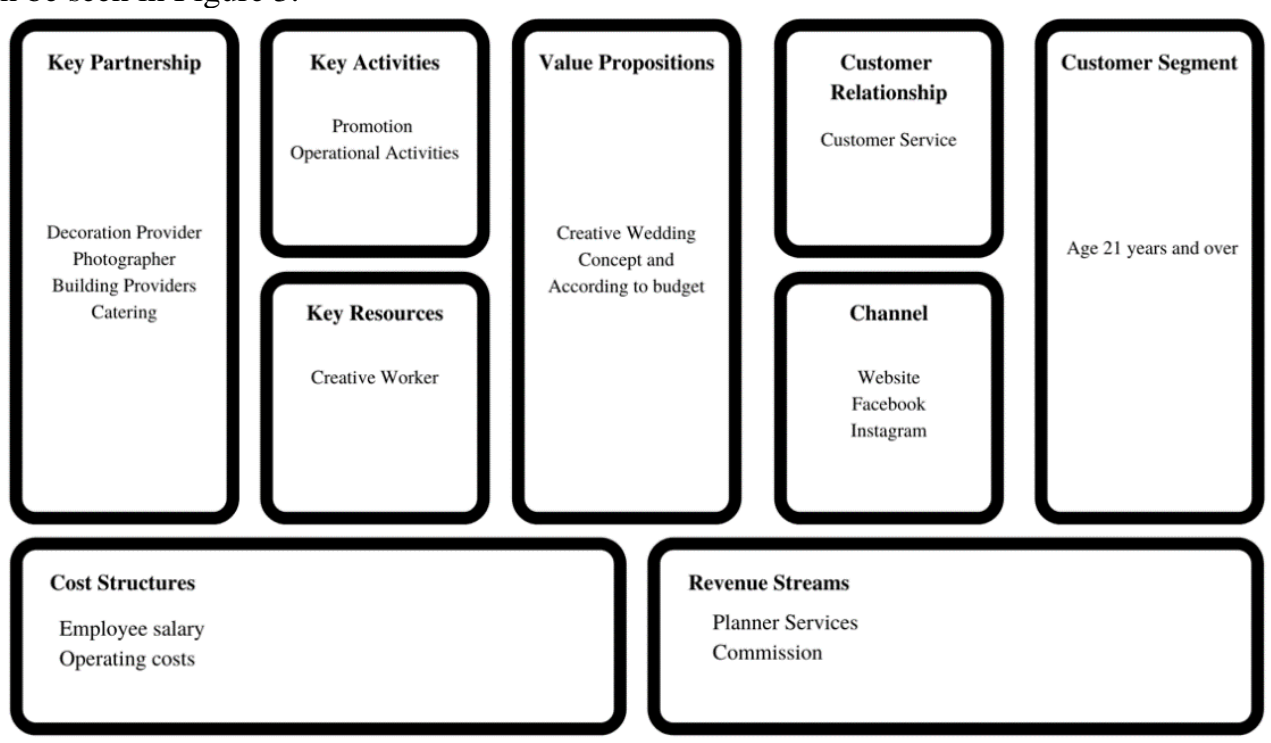

Fig 3. Visualization CV Putra Nugraha's Wedding Business Model Canvas

\subsection{Analysis of Wemary's Prospective Customer Empathy Map}

A business model's preparation begins with a map analysis as a form of a new business model [3]. The use of empathy maps needs to be done to understand and remove market segments served and accessible to consumer profiles. The empathy map formulation was carried out by distributing questionnaires to 25 potential customers of Wemary through six points of empathy maps. At disseminating the questionaire, respondents were asked to answer questionbased on what they see, hear, think and feel, say and do, pain, gain, and what we wanted to gain from Wemary's services. Table 4 below is the result of questionnaires that have been disseminated. 
Table 4. Result of questionnaires through six points of empathy maps

\begin{tabular}{|c|c|c|}
\hline Question Tool & $\begin{array}{l}\text { Responde } \\
\text { n }\end{array}$ & Feedback Customer \\
\hline \multirow[t]{2}{*}{$\begin{array}{l}\text { What do they } \\
\text { see? }\end{array}$} & $\mathrm{R} 3$ & $\begin{array}{l}\text { "Funny, unique, and a new thing in Indonesia. Hahaha more } \\
\text { practical." }\end{array}$ \\
\hline & R20 & $\begin{array}{l}\text { "Breakthroughs that are relevant to today's digital world and today's } \\
\text { practical needs." }\end{array}$ \\
\hline \multirow[t]{2}{*}{$\begin{array}{l}\text { What do they } \\
\text { hear? }\end{array}$} & $\mathrm{R} 14$ & $\begin{array}{l}\text { "Wedding online invitation is something that most people have not } \\
\text { heard much about." }\end{array}$ \\
\hline & R6 & "Ijust heard about the wedding online invitation in this questionnaire" \\
\hline \multirow[t]{2}{*}{$\begin{array}{l}\text { What do they } \\
\text { think and feel? }\end{array}$} & R4 & $\begin{array}{l}\text { "Without an invitation letter means to win the budget, and this is quite } \\
\text { profitable for the bride-to-be." }\end{array}$ \\
\hline & $\mathrm{R} 2$ & $\begin{array}{l}\text { Quite an inspiration for young people with limited funds can use this } \\
\text { so that funds to invitation letter can be allocated to others. }\end{array}$ \\
\hline \multirow{2}{*}{$\begin{array}{l}\text { What do they } \\
\text { say and do? }\end{array}$} & R9 & "It can be recorded here, suiatble for busy people." \\
\hline & $\mathrm{R} 13$ & $\begin{array}{l}\text { "Yes, I would recommend it because one of the features makes it easy } \\
\text { to give gifts, so there is no need to bother looking for gifts at the store." }\end{array}$ \\
\hline \multirow[t]{2}{*}{$\begin{array}{l}\text { What do they } \\
\text { worried about? }\end{array}$} & $\mathrm{R} 1$ & $\begin{array}{l}\text { "Perhaps not all intivations will get it, especially the elderly who } \\
\text { rarely open social media or email." }\end{array}$ \\
\hline & $\mathrm{R} 21$ & $\begin{array}{l}\text { "Invitations are nor the same if the relatioship is in the interior that } \\
\text { has difficulty accessing the internet." }\end{array}$ \\
\hline \multirow[t]{2}{*}{$\begin{array}{l}\text { What they want } \\
\text { to get? }\end{array}$} & $\mathrm{R} 2$ & $\begin{array}{l}\text { "The concept is unique and funny. The details of the concept are } \\
\text { precise." }\end{array}$ \\
\hline & R12 & "Easy of invitation delivery, cost, and time-saving." \\
\hline
\end{tabular}

Based on the result of questionnaires that have been disseminated, the empathy map vizualization used as an innovative approach to business models and understanding customer needs is presented in Figure 4.

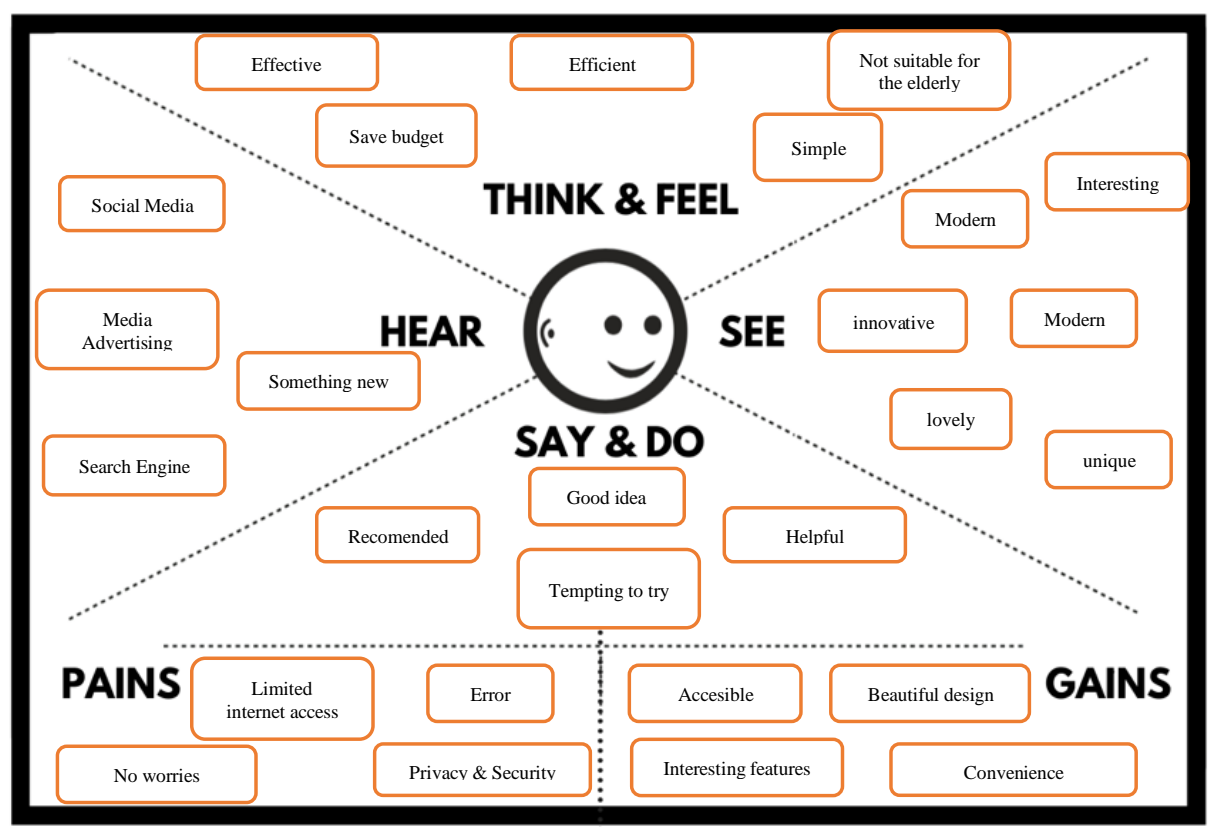

Fig 4. Empathy Map from Potential Customers of Wemary 
Based on data collected through questionnaires about what points customers see, most respondents found the services offered by Wemary exciting and new things that were tempting to try and modern and innovative breakthroughs.

However, based on the questionnaire, results in what points customers hear, there are still many who have never heard of Online Wedding Invitation services. The majority of ways consumers get information about a service or product are obtained through their immediate family and friends. According to research conducted by [3], information and recommendations from the immediate environment are the parties that greatly influence the decision to use a service.

Based on the questionnaire data on what points are felt by customers, customers want prices that can compete with printed invitations to save the budget spent on weddings. Respondents also want excellent and unique features and information such as those on printed invitations, for example, the Google Maps feature and pre-wedding photo albums. Another opinion from respondents is that the use of Wedding Online Invitation is considered very good because it can reduce paper usage and supports the Go-Green movement and is even considered to make it easier to invite friends or family who live in various cities and even abroad.

\subsection{Wemary's Integrated Wedding Website Platform Business Model}

The results of the illustration of the empathy map become one of the bases in preparing Wemary's Integrated Marriage Website Services business model. This business model innovation idea is stated in the nine components of the business model. The results of the analysis of the nine components of Wemary's Integrated Marriage Website business model are outlined in the Business Model Canvas in Figure 5.

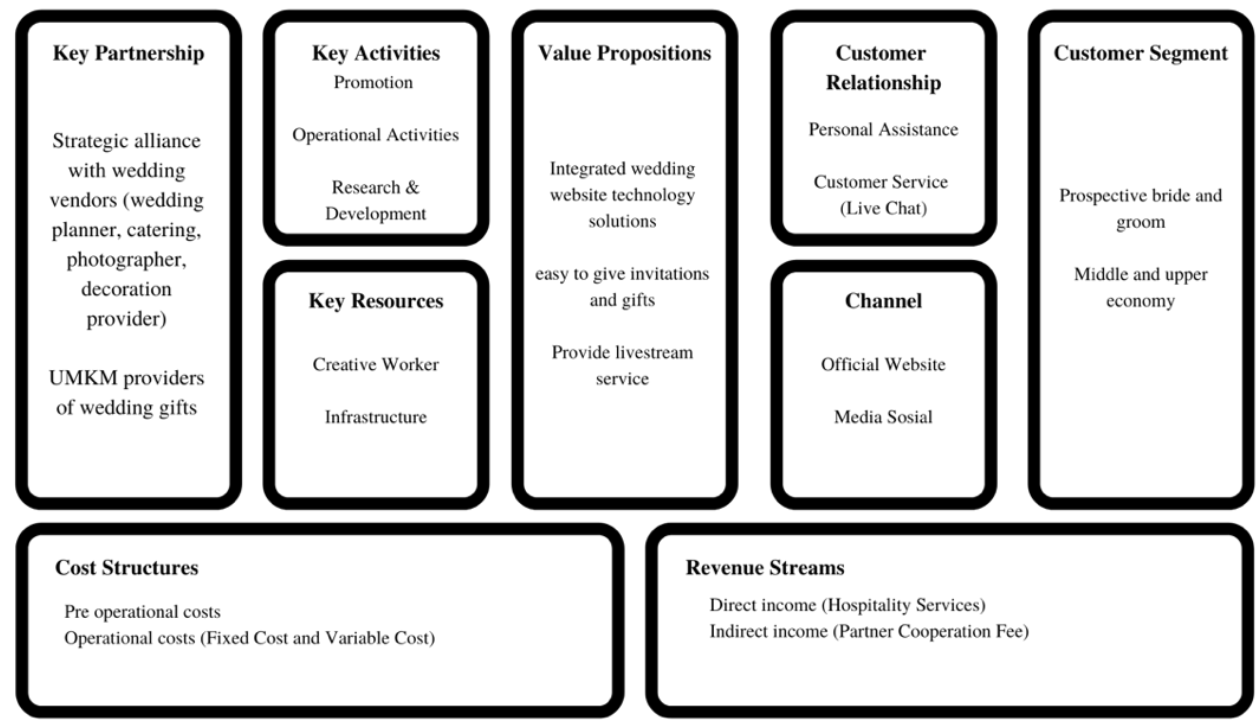

Fig 5. Wemary's Integrated Wedding Website Business Model Canvas

The questionnaire's results indicate that in terms of customer segmentation, potential users of the Integrated Wedding Website service are prospective brides who are technology literate and want ease in distributing invitations. Potential Wemary customers are between 20-35 years old. According to the results of a study by the National Population and Family Planning Board 
(BKKBN), this age is chosen. Ideally, every couple who desires to get married is a psychologically and medically appropriate age, ideally at least 21 years for women and 25 years for men [7].

Wemary's customer segmentation is people with middle to upper economic levels. Usually, consumers' characteristics in this group do not hesitate to pay considerable fees to hold memorable weddings once in a lifetime.

In terms of value proportion, Wemary is here to offer technological solutions for today's weddings. This integrated wedding services website development offers convenience in sending invitations. The features presented on the invitation website include love stories, realtime reminders, integrated Google Maps, and online RSVP. The recipient of the invitation can get information about the wedding ceremony from the bride and groom through the gadget, shown in Figure 6.
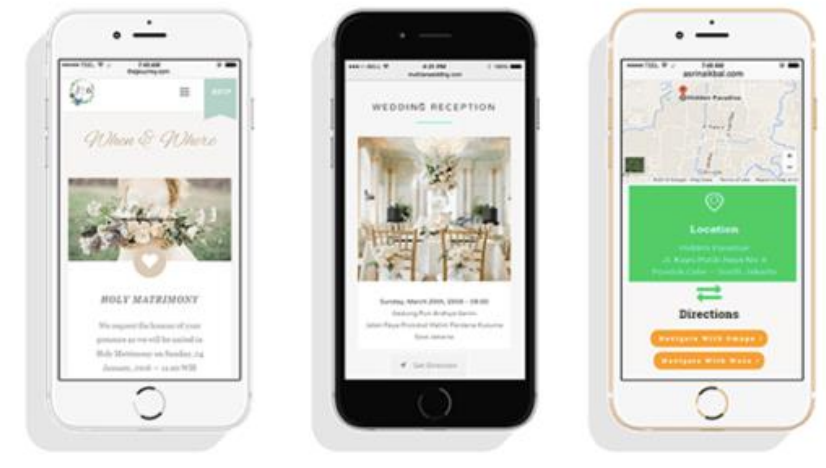

Fig. 6. Services Wemary Offered

The innovation offered by Wemary is not only online invitations. Another advantage (value) offered by Wemary for invited guests is the Givethings feature. This feature provides a wide selection of items that can be used as gifts for brides. So you do not have to worry anymore when you cannot attend, Wemary will help from wrapping the gifts to delivery. Gift wrapping can also be customized according to consumer wishes. The innovations offered by Wemary do not stop there, but currently, Wemary is also developing a live stream feature. This feature was developed to accommodate several parties who want their wedding ceremony to be watched via live stream by public or private.

The Channel section explains how Wemary communicates with customers. The digital world is a communication channel that will be used to communicate with customers. The survey results showed that the characteristics of this service users are people who are familiar with the digital world.

Official websites and social media are vital in building communication with customers. The official website provides information to the public regarding company profiles and the services Wemary offers. Social media is considered to be one of the most effective ways to communicate and interact with consumers. It is easy to share content in the form of text, images, videos, and sound so that social media is considered capable of reaching a broad market but at an affordable cost.

Wemary will use several social media, namely Facebook, Instagram, and LINE Official Account. The three social media take into account the popularity of social media use in Indonesia today. Social media functions as a means of building awareness and even building engagement with Wemary's consumers. 
In terms of customer relations, maintaining relationships with consumers is important because a well-maintained relationship will keep the company growing [11]. Since the development of the digital world, all transactions now feel easier. Not only shopping via online, negotiating and asking about products and services, you can use the Live Chat feature. Wemary presents a Live Chat feature on the official website.

The existence of this Live Chat feature on the website makes it easy to connect with potential customers. Prospective consumers don't have to bother opening other applications and even switching devices to contact Wemary. Besides facilitating communication, it will give the impression of being fast response and cost-effective. One of the benefits of using Live Chat on the website is to cut communication costs, because doing follow-up to prospective users does not require credit for sending text messages or telephone calls. Wemary Live Chat is available every day from 08.00 - 21.00 WIB.

Besides, Wemary also uses dedicated personal assistance in serving consumers. Wemary provides and assigns company representatives to be responsible for serving each customer individually. One customer will be served on an ongoing basis by one of Wemary's representatives.

The revenue stream represents the revenue the company will get from each customer [8]. In terms of income streams, Wemary's income stream is obtained through direct income and indirect income. Direct income is obtained through services or services performed. Indirect income is obtained from the cooperative relationship between partners and Wemary.

Additional income can be obtained by promoting a paid Weary. Promote paid is currently considered to be one of the most effective marketing strategies. Promote paid can be offered through the website and social media. The strategy taken to promote paid on Instagram is to do "Shoutout For Shoutout, " which promotes each other's wedding vendors on Instagram.

Resources are the main thing that companies need in running their business. Every company requires different and diverse resources [11]. In terms of Main Resources, the main resources Wemary need are human resources and supporting infrastructure.

Regarding the services offered, Wemary is required to always provide innovation and service development. The idea of resources and creativity is a driving force in innovation and development, so that human resources are considered the most important assets of the company in providing creative ideas and ideas in the continuity of Wemary's business and business.

In supporting business continuity, Wemary needs to build and manage infrastructure. This infrastructure consists of a set of software tools and applications that Wemary needs to run its business, namely hardware, software, data storage management, and network / telecommunications platforms.

In terms of Key Activities, Wemary's main activities are carrying out operational activities and conducting promotions. Its operational activities help handle clients in making attractive online invitations for their weddings. Apart from carrying out operational activities, an activity that is no less important is conducting promotions. Promotion is a marketing step that companies need to take to maintain business stability. Promotions carried out by Wemary are divided into two activities: offline activities and online activities, both of which support each other. Wemary's offline activities include participating in wedding exhibitions, Corporate Social Responsibility activities through "Golek Garwo" and "Marriage Together." Meanwhile, Wemary's online activities include creating marketing campaigns on Facebook and Instagram.

Another activity that Wemary does is Research \& Development (RnD). RnD activity is an effort to develop a new feature or improve existing services. RnD's activities' purpose is to create a value-added that has not been offered by competitors, and Wemary can be at the forefront of innovation. 
In the business world, establishing partnerships with other business actors is an effort to ensure business processes' success. In terms of Key Partnerships, one form of business partnership that Wemary will undertake is a strategic partnership, Wemary collaborates with other wedding vendors. The purpose of this collaboration is to strengthen Wemary's marketing network.

\section{CONCLUSION}

The formulation of a business model using the nine components of the canvas business model can provide an overview and hints for getting innovation in business development. Formulating an integrated business model of a wedding website platform is carried out to provide social benefits for consumers, optimal profits for the company, and strengthen corporate partnership synergies.

Acknowledgments. Thanks to the Vocational School of Diponegoro University, the Innovative Academy of Gadjah Mada University, CV Marriage Putra Nugraha, and the Wemary Team helped a lot with the data and the implementation of this research.

\section{REFERENCES}

[1] Akselerasi.id. [Online]. Available: https://akselerasi.id/media/Materi_13_Business_Model_Canvas.pdf,. [Accessed: 15Apr-2020].

[2] Z. Lindgardt, M. Reeves, G. Stalk Jr, and M. Deimler, "Business model innovation: When the game gets tough, change the game," in Own the Future, Hoboken, NJ, USA: John Wiley \& Sons, Inc., 2015, pp. 291-298.

[3] A. Cahyani, "Model Bisnis Ngelamar EO"," Magister Manajemen Universitas Gadjah Mada, Yogyakarta, 2015.

[4] T. Clark, A. Osterwalder, and Y. Pigneur, Business Model You. Hoboken, New Jersey: John Wiley \& Sons, Inc, 2013.

[5] D. Kiron, N. Kruschwitz, K. Haanaes, M. Reeves, and E. Goh, The Innovation Bottom Line. Cambridge: MIT Sloan, 2013.

[6] E. Giesen, E. Riddleberger, R. Christner, and R. Bell, "When and how to innovate your business model," Strat. Lead.., vol. 38, no. 4, pp. 17-26, 2010.

[7] Binus.ac.id. [Online]. Available: http://sbm.binus.ac.id/2016/06/25/keywords-weddingorganizer-produk-high-involvement-dan-arti-penting-pesta-pernikahan-padamasyarakat-indonesia/,. [Accessed: 30-Mar-2021].

[8] A. Osterwalder and Y. Pigneur, Business model generation: A handbook for visionaries, game changers, and challengers, 1st ed. Chichester, England: John Wiley \& Sons, 2013.

[9] E. Ries, The Lean Startup. New York, NY: Crown Business Division, 2011.

[10] M. Sako, "Technology Strategy and Management. Business Models for Strategy and Innovation"," Communications of the ACM, vol. 55, no. 7, pp. 22-24, 2012. 
[11] A. Setiobudi, Make a Wish Birthday Party Planner. Thesis, MM UGM: Yogyakarta, 2016.

[12] "Tech in Asia Indonesia - komunitas online Startup di Asia," Techinasia.com. [Online]. Available: https://id.techinasia.com/bingung-rencanakan-pernikahan-bridestory-siapmembantu-anda,. [Accessed: 22-Jul-2019].

[13] D. J. Teece, "Business Models, Business Strategy and Innovation," Long Range Planning, vol. 43, pp. 172-194, 2010.

[14] C. Zott, R. Amit, and L. Massa, "The Business Model: Theoretical Roots, Recent Developments, and Future Research," University of Navarra: IESE Business School, 2010. 